\title{
Innæða krabbameinslyfjameðferð með slagæðastíflun: Árangur staðbundinnar krabbameinsmeðferðar á Íslandi
}

Pórarinn Árni Bjarnason læknanemi, Haraldur Bjarnason ${ }^{1,2}$ læknir, Óttar Már Bergmann ${ }^{3}$ lknir, Hjalti Már Pórisson¹,4,5 læknir

\section{ÁGRIP}

Inngangur: Innæðakrabbameinslyfjameðferð með slagæðastíflun er staðbundin krabbameinsmeðferð til að meðhöndla krabbamein í lifur. Meðferðin er líknandi en getur einnig nýst með skurðaðgerð og/eða rafbrennslu. Hún getur einnig nýst til að halda sjúklingum á lifrarígræðslulista eða niðurstiga sjúkdóminn svo peir komist á slíkan lista. Markmið rannsóknarinnar var að kanna árangur staðbundinnar krabbameinsmeðferðar og tíðni fylgikvilla á Íslandi.

Efni og aðferðir: Gerð var afturskyggn klínísk rannsókn sem náđi til allra sem fengu innæðakrabbameinslyfjameðferð með slagæðastíflun, slagæðastíflanir og innæðakrabbameinslyfjagjafir á Íslandi frá 1. maí 2007 til 1. mars 2011. Upplýsingar voru fengnar úr sjúkraskrárkerfi og myndgeymslukerfi Landspítala.

Niðurstöður: Pað hafa verið framkvæmdar 18 innæðakrabbameins- lyfjameðferðir með slagæðastíflun, 6 slagæðastíflanir og tvær svæðisbundnar krabbameinslyfjameðferðir til að meðhöndla 9 sjúklinga með lifrarfrumukrabbamein og prjá með meinvörp frá krabbalíki. Meðallifun sjúklinga með lifrarfrumukrabbamein var 15,2 mánuðir og hjá sjúklingum með krabbalíkismeinvörp 61 til 180 mánuðir. Alger svörun varð tvisvar og hlutasvörun fjórum sinnum. Sjúkdómurinn hélst stöđugur í 11 skipti en versnaði í premur tilvikum. Minniháttar fylgikvillar greindust eftir 6 af 26 inngripum. Einu sinni kom upp meiriháttar fylgikvilli. Enginn fékk lifrarbilun sem rekja má til inngripsins. Einn sjúklingur með lifrarfrumukrabbamein var á lifrarígræðslulista fyrir meðferð og tókst að halda honum á lista fram að ígræðslu. Pá tókst að niðurstiga prjá svo peir komust á listann. Ályktun: Árangur staðbundinnar krabbameinsmeðferðar er viðunandi hér á landi og eru fylgikvillar í kjölfar inngripsins innan marka.
Læknadeild Háskóla Íslands, ${ }^{2}$ Department of Radiology, Mayo

\section{Inngangur}

Innæðakrabbameinslyfjameðferð með slagæðastíflun, IKSS (Transcatheter arterial chemoembolization, TACE), er ein tegund staðbundinnar krabbameinsmeðferðar (logoregional therapy) og er meðferðarmöguleiki við krabbamein í lifur. Inngripið felur í sér að æðaleggur er præddur um náraslagæð og paðan um lifrarslagæð að peirri slagæðagrein sem nærir æxlið. Pá er blöndu af krabbameinslyfjum, með eða án joðs í olíufasa (ethiodized oil), og æðastíflandi efnum gefið í slagæðina sem nærir krabbameinið. ${ }^{1}$ Í IKSS á Íslandi er gefið doxurubicin og mitomycin ásamt joði í olíufasa og pólývinýl-alkóhólagnir Til eru aðrar tegundir staðbundinnar krabbameinsmeðferðar eins og innæðakrabbameinslyfjagjöf (trans-arterial chemotherapy) og slagæðastíflun (bland embolization).

Markmið IKSS er að ná háum styrk frumudrepandi krabbameinslyfja í krabbameininu og stuðla að blóðpurrð í æxlinu. Á sama tíma er magni krabbameinslyfja sem fer út í almennu blóðrásina haldið í lágmarki (mynd 1). ${ }^{2}$ IKSS er líknandi meðferð sem hefur að markmiði að meðhöndla óskurðtæk krabbamein og meinvörp í lifur, einkum lifrarfrumukrabbamein (hepatocellular carcinoma, HCC) og meinvörp frá krabbalíki (carcinoid).,3 Inngripið getur einnig nýst með skurðaðgerð og rafbrennslu (radiofrequency ablation) og stuðlað að niðurstigun krabbameinsins og par af leiðandi gert lifrarígræðslu að möguleika fyrir pessa sjúklinga. ${ }^{5}$ Pá hafa rannsóknir bent til pess að IKSS geti gagnast sjúklingum með gallgangakrabbamein (cholangiocarcinoma) og meinvörp í lifur frá briseyjaæxlum og stoðvefjaæxlum. ${ }^{6,7}$

Ekki geta allir sjúklingar með óskurðtæk krabbamein í lifur gengist undir IKSS. Helstu frábendingar við IKSS eru léleg lifrarstarfemi (Child's-flokkur C) með lélegu blóðflæði til lifrarinnar, illvíg sýking og ef hægt er að fjarlægja æxlið með skurðaðgerð. Einnig verður að sýna sérstaka varúð ef sjúklingur er með bilirúbín hærra en $40 \mathrm{mg} / \mathrm{L}$, prengsli í portal-bláæðinni, galla í blóðstorkukerfi, slag- og bláæða-æðatengingu (arteriovenous shunt) um æxlið og lifrarheilakvilla.

IKSS var fyrst lýst 1977 en um síðustu aldamót komu fram rannsóknir sem sýndu fram á betri lifun sjúklinga með lifrarfrumukrabbamein sem meðhöndlaðir voru með IKSS miðað við sjúklinga sem gengust undir hefðbundna meðferð. ${ }^{3,8}$ Síðastliðin 15 ár hefur IKSS verið helsta meðferð við óskurðtækum krabbameinum í lifur. Í maí 2007 var gerð fyrsta slagæðastíflunin á Íslandi til að meðhöndla lifraræxli og fyrsta IKSS var gerð í október 2009. Núna gangast allir sjúklingar sem fara í staðbundna krabbameinsmeðferð til meðhöndlunar á krabbameini í lifur, undir IKSS.

Árangur IKSS og annarra staðbundinna krabbameinsmeðferða til að meðhöndla æxli í lifrinni hefur ekki verið skoðaður á Íslandi. Megintilgangur pessarar 

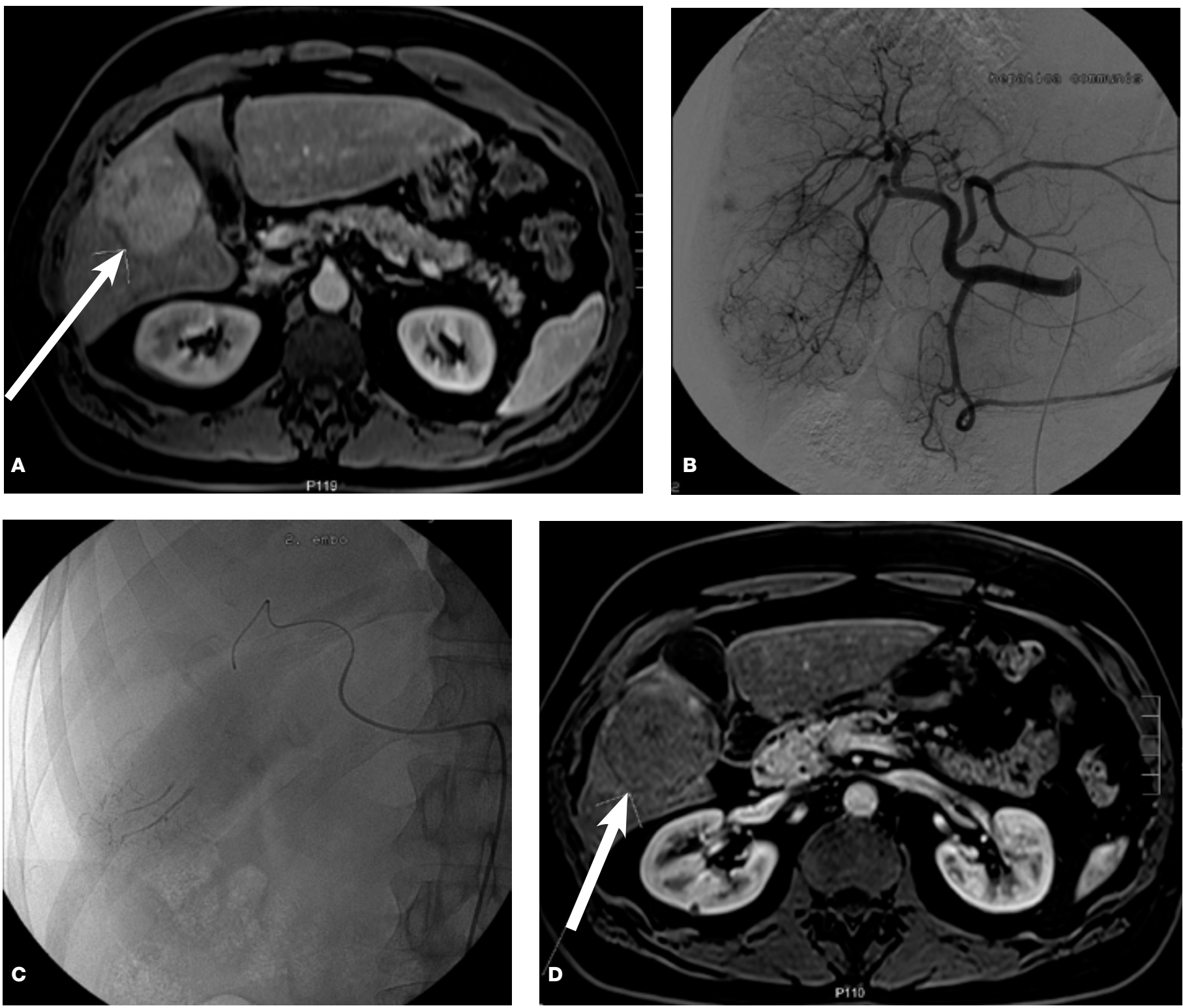

Mynd 1. Lifrarfrumukrabbamein meðhöndlað með IKSS: 53 ára karlmaður með stóra fyrirferð í lifur sem hleður ríkulega upp skuggaefni á T1-viktaðri mynd í slagæðarfasa eftir skuggaefnisgjöf (mynd 1a) sem kom í IKSS-meðferð. Hefðbundin æðamyndataka sýnir ríkulegt blóðflæði frá greinum hægri lifrarslagæðar (mynd 1b) en pessar greinar voru síðan præddar með æðalegg (mynd 1c) og IKSS-meðferð veitt. Segulómun fjórum vikum eftir meðferð sýnir nánast enga upphleðslu í fyrirferðinni á T1-viktaðri mynd í slagæðafasa eftir gjöf skuggaefnis (mynd 1d).

rannsóknar var að kanna árangur staðbundinna krabbameinsmeðferða á Íslandi og skoða tíðni fylgikvilla sem koma upp í kjölfar inngripanna.

\section{Efniviður og aðferðir}

Rannsóknin var gerð á röntgendeild Landspítala í Fossvogi og náði til allra IKSS, slagæðastíflna og innæðakrabbameinslyfjagjafa sem gerðar voru á Íslandi frá 1. maí 2007 til 1. mars 2011. Rannsóknin var afturskyggn klínísk rannsókn og voru upplýsingar fengnar úr sjúkraskrárkerfi og myndgeymslukerfi Landspítala. Rannsóknin var sampykkt af vísindasiðanefnd og Persónuvernd.

Safnað var saman upplýsingum um aldur sjúklinga, kyn, lengd innlagnar eftir inngrip og um hugsanlega lifrarsjúkdóma og áhættupætti fyrir lifrarfrumukrabbamein. Skoðuð var stærð stærsta æxlisins í lifrinni, fjöldi æxla og samanlagt pvermál æxlisvefjar og kannað hvort kominn væri ífarandi vöxtur í æðar, eitil- meinvörp eða fjarmeinvörp. Lifun sjúklinga og tími án versnunar sjúkdóms (progession free survival) voru skilgreind frá greiningu til andláts eða frá greiningu til 1. mars 2011, pegar rannsóknartímabilinu lauk. Sjúklingunum var skipt í tvo hópa, pá sem voru með lifrarfrumukrabbamein og pá sem höfðu meinvörp í lifur frá krabbalíki. Pessi aðgreining var viðhöfð par sem mikill munur er á hegðun pessara krabbameina, horfum sjúklinga og klínískum ábendingum.

Sjúklingar með lifrarfrumukrabbamein voru stigaðir samkvæmt CLIP-stigunarkerfinu fyrir fyrsta inngrip sem spáir fyrir horfum sjúklinga með lifrarfrumukrabbamein. ${ }^{9}$ Lifrarstarfemi sjúklinga var metin fyrir fyrsta inngrip og svo fjórum vikum eftir hvert inngrip samkvæmt ChildPugh-skori (Child's) og MELDskori (Model of End-stage Liver Disease) sem spáir fyrir horfum sjúklinga með skorpulifur. ${ }^{10,11}$ Svörun æxlisins við inngripinu var metin með segulómun (MRI) eða tölvusneiðmynd (CT) fjórum vikum eftir hvert inngrip með hliðsjón af mRECIST (tafla I). ${ }^{12}$ Til 
Tafla I. Modified Response Evaluation Criteria in Solid Tumors (mRECIST)

\begin{tabular}{ll}
\hline Alger svörun & Engin upphleðsla skuggaefnis í æxlum \\
\hline Hlutasvörun & $\begin{array}{l}\text { Að lágmarki } 30 \% \text { minnkun á pvermáli lífvænlegs } \\
\text { krabbameinsvefs (sem tekur upp skuggaefni) } \\
\text { miðað við samanlagt pvermál fyrir meðferð }\end{array}$ \\
\hline Stöðugur sjúkdómur & $\begin{array}{l}\text { Fellur ekki undir hlutasvörun eða versnun á } \\
\text { sjúkdómnum }\end{array}$ \\
\hline Versnun sjúkdóms & $\begin{array}{l}\text { Að lágmarki 20\% aukning á pvermáli lífvænlegs } \\
\text { krabbameinsvefs (sem tekur upp skuggaefni) } \\
\text { miðað við samanlagt pvermál fyrir meðferð. Nýtt } \\
\text { æxli er sjálfkrafa skilgreint sem versnun sjúkdóms }\end{array}$ \\
\hline
\end{tabular}

að meta árangur niðurstigunar á krabbameininu til lifrarígræðslu var miðað við hvort sjúklingar kæmust á lifrarígræðslulistann á Sahlgrenska-sjúkrahúsinu í Svípjóð (sem framkvæmir pessar aðgerðir fyrir Íslendinga) en hjá peirri stofnun er miðað við San Francisco-viðmiðin (tafla II) til að velja sjúklinga í lifrarígræðslu. ${ }^{13}$

Fylgikvillum var skipt í meiriháttar og minniháttar fylgikvilla. Ef sjúklingur lá inni lengur en tvær nætur í kjölfar inngrips eða purfti að leggjast aftur inn eftir útskrift voru ástæður pess skoðaðar. Ef ástæðan fyrir lengdri innlögn var æðastíflunarheilkenni (post-embolization syndrome), blæðingar á stungustað eða annað minniháttar vandamál tengt inngripinu, var pað skilgreint sem minniháttar fylgikvilli. Hins vegar ef ástæðan var lifrarkýli, gallblöðrubólga, blóðsýking, varanleg lifrarbilun, lifrarnýrna-heil-
Tafla II. San Fransisco-viðmið til lifrarígræðs/u.

Eitt æxli að hámarki 6,5 cm í pvermál eđa

Að hámarki prjú æxli, öll minni en $4,5 \mathrm{~cm}$ og samtals minni en $8 \mathrm{~cm}$ í pvermá

Að auki er hægt að framkvæma IKSS og/eða rafbrennslu til að minnka

krabbameinsvefinn svo sjúklingur falli undir viðmiðin

kenni (hepatorenal syndrome), æðastíflun í lungum eða heila eða annað sem krafðist skurðaðgerðar vegna inngripsins, var pað skilgreint sem meiriháttar fylgikvilli. Jafnframt var andlát innan 30 daga frá inngripi skilgreint sem meiriháttar fylgikvilli, án tillits til orsaka.

\section{Niðurstöður}

\section{Lifrarfrumukrabbamein}

Gerðar hafa verið 16 IKSS, tvær slagæðastíflanir og tvær innæðakrabbameinslyfjagjafir til að meðhöndla 9 sjúklinga, par af 7 karla, með lifrarfrumukrabbamein. Af peim var einn sjúklingur með sambland af lifrarfrumu- og gallvegakrabbameini (tafla III, sjúklingur nr. 7). Sjúklingarnir voru á aldrinum 49-86 ára við greiningu og meðalaldur 66 ár. Af 9 sjúklingum voru 5 með skorpulifur. Tveir sjúklingar höfðu sögu um ofnotkun áfengis, tveir voru með langvinna lifrarbólgu C sýkingu, einn var með járngeymdarkvilla

Tafla III. Lýðfræði og ástand sjúklinga.

\begin{tabular}{|c|c|c|c|c|c|c|c|c|c|c|c|c|}
\hline Sjúklingur nr. & 1 & 2 & 3 & 4 & 5 & 6 & 7 & 8 & 9 & 10 & 11 & 12 \\
\hline Kyn & KK & KK & KK & KVK & $\mathrm{KK}$ & KK & KVK & KK & KK & KVK & KK & KK \\
\hline Aldur & 53 & 58 & 76 & 75 & 59 & 49 & 72 & 86 & 66 & 58 & 54 & 62 \\
\hline Krabbamein & $\mathrm{HCC}$ & $\mathrm{HCC}$ & $\mathrm{HCC}$ & $\mathrm{HCC}$ & $\mathrm{HCC}$ & $\mathrm{HCC}$ & $\mathrm{cHCC}-\mathrm{CC}$ & $\mathrm{HCC}$ & $\mathrm{HCC}$ & Krabbalíki & Krabbalíki & Krabbalíki \\
\hline Áhættupættir & $\mathrm{HCV}$ & Áfengi & Engir & PBC & Áfengi & $\mathrm{HCV}$ & Engir & Engir & $\begin{array}{l}\text { Járngeymdar- } \\
\text { kvilli }\end{array}$ & Á.e.v. & Á.e.v. & Á.e.v. \\
\hline Skorpulifur & $\mathrm{Nei}$ & Já & $\mathrm{Nei}$ & Já & Já & Já & $\mathrm{Nei}$ & $\mathrm{Nei}$ & Já & $\mathrm{Nei}$ & $\mathrm{Nei}$ & $\mathrm{Nei}$ \\
\hline IKSS & 4 & 3 & 1 & 1 & 3 & 3 & 1 & 0 & 0 & 1 & 1 & 0 \\
\hline Slagæðastíflun & 0 & 0 & 0 & 0 & 0 & 0 & 1 & 1 & 0 & 0 & 2 & 2 \\
\hline $\begin{array}{l}\text { Svæðisbundin } \\
\text { krabbameinslyfjameðferð }\end{array}$ & 0 & 0 & 0 & 0 & 0 & 0 & 0 & 0 & 2 & 0 & 0 & 0 \\
\hline CLIP & 1 & 1 & 1 & 2 & 2 & 2 & 0 & 2 & 2 & Á.e.v. & Á.e.v. & Á.e.v. \\
\hline Child's & $A$ & $A$ & $A$ & $A$ & $\mathrm{~B}$ & B & A & $A$ & $A$ & Á.e.v. & Á.e.v. & Á.e.v. \\
\hline MELD & 7 & 10 & 8 & 9 & 10 & 16 & 7 & 9 & 7 & Á.e.v. & Á.e.v. & Á.e.v. \\
\hline Portæðaháprýstingur & Nei & Já & Nei & Nei & Já & Já & Nei & Nei & Nei & Nei & Nei & Nei \\
\hline Heildarstærð æxlis* & 8,5 & 8,5 & 5,3 & 8,1 & 5,9 & 12,4 & 10 & 20 & 7,5 & 18,7 & ÓM & 22,6 \\
\hline Stærsta æxli & 7 & 5 & 3,7 & 6,2 & 5,1 & 7,4 & 10 & 15 & 3,5 & 5,7 & 4,4 & 14,2 \\
\hline Fjöldi æxla & 3 & 2 & 2 & 2 & 2 & 2 & 1 & $>10$ & 4 & 6 & $>10$ & 4 \\
\hline Meinvörp & Nei & Nei & Nei & Í eitla & $\mathrm{Nei}$ & $\mathrm{Nei}$ & $\mathrm{Nei}$ & $\mathrm{Nei}$ & $\mathrm{Nei}$ & Á.e.v. & Á.e.v. & Á.e.v. \\
\hline Æモðaíferð & $\mathrm{Nei}$ & $\mathrm{Nei}$ & $\mathrm{Nei}$ & Já & Nei & $\mathrm{Nei}$ & $\mathrm{Nei}$ & $\mathrm{Nei}$ & $\mathrm{Nei}$ & Á.e.v. & Á.e.v. & Á.e.v. \\
\hline
\end{tabular}

IKSS = Innæðakrabbameinslyfjameðferð með slagæðastíflun, CLIP = Cancer of the Liver Italian Program Classification,

MELD = Model for End-stage Liver Disease, KK = Karl, KVK = Kona, HCC = Lifrarfrumukrabbamein,

cHCC-CC = Sambland lifrarfrumu- og gallvegakrabbameins, $\mathrm{HCV}=$ Lifrarbólga $\mathrm{C}, \mathrm{PBC}=$ Gallskorpukvilli, Á.e.v. = Á ekki við,

ÓM = Ómælanlegt

*Pvermál mælt í cm 
Tafla IV. Lifrarstarfsemi og lýsing á æxlum fyrir inngrip.

\begin{tabular}{lc}
\hline Fjöldi sjúklinga Child's A & 7 \\
\hline Fjöldi sjúklinga Child's B & 2 \\
\hline Meðaltal MELD & $9,2(6-40)$ \\
\hline Meðaltal fjölda æxla & 3 \\
\hline Meðaltal heildarpvermáls æxla & $9,6 \mathrm{~cm}$ \\
\hline
\end{tabular}

MELD =Model for End-stage Liver Disease

og einn með frumkominn gallskorpukvilla (primary biliary cirrhosis, PBC). Prír sjúklinganna höfðu ekki sögu um áhættupætti fyrir lifrarfrumukrabbameini. Heildarstærð krabbameinsæxlisins var á bilinu 5,3-20 cm í pvermál. Að meðaltali var heildarstærð æxla 9,6 cm í pvermál og miðgildi var $8,5 \mathrm{~cm}$ í pvermál. Meðalfjöldi æxla voru prjú og miðgildi tvö (tafla IV). Einn sjúklingur var með svo mörg æxli að ekki var unnt að telja pau. Í pví tilviki var fjöldi æxla skilgreindur sem fleiri en 10.

Lifun sjúklinga var á bilinu 5-28 mánuðir og var meðallifun 15,2 mánuðir og miðgildi lifunar 15 mánuðir. Á rannsóknartímabilinu létust tveir sjúklingar. Annar sjúklingurinn hafði gengist undir eina IKSS en hinn undir eina slagæðarstíflun. Pannig voru 7 sjúklingar með lifrarfrumukrabbamein, sem gengist hafa undir inngripin, á lífi 1. mars 2011. Tími án versnunar sjúkdóms var á bilinu 0-28 mánuðir og að meðaltali 11,4 mánuðir og miðgildi 10 mánuðir. Af 7 sjúklingum hafa tveir sýnt merki um versnun á sjúkdómnum.

Tvisvar varð alger svörun samkvæmt mRECIST og fjórum sinnum varð svörun að hluta til. Sjúkdómurinn hélst stöðugur í 9 tilvikum en í tveimur tilvikum hélt sjúkdómurinn áfram að versna eftir inngrip (tafla V). Sumir sjúklingar eru taldir tvisvar í pessum gögnum par sem peir fengu bæði svörun eftir meðferð og síðar meir átti sér stað versnun á sjúkdómnun. Að meðaltali minnkaði pvermál æxlanna um $1,2 \mathrm{~cm}$.

Child's-flokkunin hélst óbreytt, annaðhvort sem A eða B, í 15 tilfellum. Í eitt skipti mældist lifrarstarfsemi betri pegar sjúkling- ur fór úr Child’s-flokki B í flokk A í kjölfar IKSS. Í einu tilviki versnaði lifrarstarfsemin úr Child's-flokki A í flokk B í kjölfar IKSS og rafbrennslu. Óvíst er hvort um var að ræða varanlega versnun á lifrarstarfsemi par sem sjúklingurinn fór í lifrarígræðslu tveimur vikum eftir blóðsýnatöku. Child’s-skorið var ópekkt í premur tilvikum. MELD-skorið breyttist lítið og var meðaltal og miðgildi pess 8 eftir inngripin. Рað var á bilinu 6-9 eftir 11 inngrip og í kjölfar 6 inngripa var MELD-skorið á bilinu 10-13. MELD-skorið var ópekkt í premur tilvikum.

\section{Meinvörp frá krabbalíki}

Á rannsóknartímabilinu voru gerðar tvær IKSS og fjórar slagæðarstíflanir til að meðhöndla prjá sjúklinga með meinvörp í lifur frá krabbalíki, par af tvo karla (tafla III, sjúklingar nr. 10-12). Aldur sjúklinga var 54, 58 og 62 ár. Lifun sjúklinganna sem undirgengust IKSS var 61, 156 og 180 mánuðir. Í töflu VI er yfirlit yfir æxlissvörun krabbalíkismeinvarpanna. Einn sjúklingur með krabbalíki lést á rannsóknartímabilinu vegna hjartabilunar. Allir sjúklingar með meinvörp í lifur frá krabbalíki voru á sómatóstatín-hliðstæðu til að meðhöndla einkenni vegna krabbalíkisheilkennis. Einn sjúklingur hafði áđur verið meðhöndlaður í Svípjóð með geislavirkri sómatóstatín-hliðstæðu. Helsta markmið inngripanna var að draga úr krabbalíkisheilkenni. Samkvæmt sjúkraskrám dró úr einkennum krabbalíkisheilkennis í kjölfar 5 af 6 inngripum.

\section{Fylgikvillar}

Miðgildi innlagnartíma voru tvær nætur. Í 6 tilvikum lá sjúklingur lengur en tvær næutur inni á Landspítala. Í einu tilviki var pað vegna tímabundinnar versnunar á krabbalíkisheilkenni og í 5 tilvikum vegna æðastíflunarheilkennis. Að auki var í einu tilviki valhjartapræðing ástæða fyrir lengdri innlögn og pað er ekki skilgreint sem fylgikvilli. Auk pess lagðist einn sjúklingur aftur inn vegna æðastíflunarheilkennis eftir að hafa verið útskrifaður. Af 26 inngripum hafa minniháttar fylgikvillar átt sér stað í 6 tilvikum, par af varð einn sjúklingur tvisvar fyrir minniháttar fylgikvilla. Einn sjúklingur lést 15 dögum eftir að hafa gengist undir

Tafla V. AExlissvörun og árangur. Lifrarfrumukrabbamein.

\begin{tabular}{|c|c|c|c|c|c|c|c|c|c|c|}
\hline Sjúklingur & 1. inngrip & 2. inngrip & 3. inngrip & 4. inngrip & Lifun* & $\mathrm{PFS}^{*}$ & Á lífi & Niðurstigun & Lifrarígræðsla & Athugasemdir \\
\hline 1 & HS & EM & AS & VS & 15 & 10 & Já & Já & $\mathrm{Nei}$ & VS í eftirfylgni 6 mán. eftir 3 . inngrip \\
\hline 2 & HS & SD & AS & - & 10 & 10 & Já & Já & Já & Rafbrennsla samfara 3. inngripi \\
\hline 3 & HS & - & - & - & 23 & 23 & Já & Nei & Nei & HS í eftirfylgni einu ári eftir 1 . inngrip \\
\hline 4 & VS & - & - & - & 10 & 0 & Nei & Nei & $\mathrm{Nei}$ & Lést 9 mán. eftir 1 . inngrip \\
\hline 5 & SS & SS & SS & - & 15 & 15 & Já & Á.e.v. & Já & Á lifrarígræðslulista fyrir inngrip \\
\hline 6 & EM & HS & SS & - & 6 & 6 & Já & Nei & Nei & \\
\hline 7 & SS $^{1}$ & SS & - & - & 25 & 11 & Já & Nei & $\mathrm{Nei}$ & $\begin{array}{l}\text { VS í eftirfylgni } 9 \text { mán. eftir } 1 \text {. inngrip } \\
\text { VS í eftirfylgni einu ári eftir } 2 \text {. inngrip }\end{array}$ \\
\hline 8 & $\mathrm{EE}^{1}$ & - & - & - & 5 & 0 & Nei & Nei & $\mathrm{Nei}$ & Lést 4 mán. eftir 1 . inngrip \\
\hline 9 & $\mathrm{SD}^{2}$ & $\mathrm{SD}^{2}$ & - & - & 28 & 28 & Já & Já & Já & \\
\hline
\end{tabular}

PFS = Tími án versnunar sjúkdóms, AS = alger svörun, HS = hlutasvörun, $S S$ = stöðugur sjúkdómur, VS = versnun sjúkdóms, EM = ekki myndgreint milli inngripa, EE = engin eftirfylgni Á.e.v. $=$ Á ekki við

*Mánuð̌ir, 'Slagæðastíflun, ${ }^{2}$ Innæðakrabbameinslyfjagjöf 
Tafla VI. AExlissvörun. Meinvörp frá krabbalíki.

\begin{tabular}{cccccc}
\hline Sjúklingur & 1. inngrip & 2. inngrip & 3. inngrip & Lifun* $^{*}$ & Á lífi \\
\hline 10 & SS & - & - & 156 & Já \\
\hline 11 & $\mathrm{EM}^{1}$ & $\mathrm{VS}^{1}$ & $\mathrm{EE}$ & 61 & Já \\
\hline 12 & $\mathrm{SS}^{1}$ & $\mathrm{EE}^{1}$ & - & 180 & Nei \\
\hline
\end{tabular}

$\mathrm{SS}=$ stöđugur sjúkdómur, VS = versnun sjúkdóms, $\mathrm{EM}=$ ekki myndgreint milli inngripa $\mathrm{EE}=$ engin eftirfylgni

*Mánuðir, ${ }^{1}$ Slagæðastíflun

slagæðastíflun. Pessi sjúklingur var með lokastigs hjartabilun og dreifðan krabbalíkissjúkdóm. Samkvæmt sjúkraskrám var dánarorsök hjartabilun og ekki talin vera bein afleiðing inngripsins. prátt fyrir pað er petta tilvik skilgreint sem meiriháttar fylgikvilli.

\section{Umræða}

Eldri rannsóknir hafa gefið til kynna að íslenskir áfengissjúklingar og aðrir sjúklingar með lifrarsjúkdóma greinist á fyrri stigum en pekkist hjá svipuðum hópum erlendis. ${ }^{14,15}$ Pví er hugsanlegt að hlutfallslega fleiri sjúklingar á Íslandi hafi nógu góða lifrarstarfsemi við greiningu til að gangast undir IKSS en sjúklingar erlendis. Ekkert bendir til að verið sé að ofmeðhöndla pessa sjúklinga. Allir sjúklingarnir voru með nokkuð góða lifrarstarfsemi (Child’s-flokkur A eða B) og enginn var stigaður hærra en á 2. stigi CLIP-stigunarkerfisins. Hjá tveimur sjúklingum var sjúkdómurinn langt genginn pegar peir gengust undir inngripin. Annar var kominn með meinvörp í eitla og íferð í æðar, hinn var með fleiri en 10 æxlishnúta í lifur og samtals með $20 \mathrm{~cm}$ æxlisvef í pvermál pegar hann gekkst undir slagæðastíflun. Í pessum tilvikum virðist óljóst hvort ávinningur sjúklinganna vegi pyngra en áhættan sem felst í inngripunum. Hins vegar voru báðir sjúklingarnir með viðunandi lifrarstarfsemi samkvæmt Child's- og MELD-skori og inngripin pví talin vera besti kostur sjúklinganna. Lifrarstarfsemi hélst óbreytt í kjölfar inngripanna og ekkert bendir til pess að peir hafi orðið fyrir skaða sem rekja má til inngripanna. Ljóst er að sjúklingur með útbreiddan sjúkdóm hefur minni ávinning af IKSS en sjúklingur með staðbundnari sjúkdóm. Hins vegar er erfitt að meta hvenær áhættan fer að vega meira en ávinningurinn. Í raun parf að skoða hvert tilfelli fyrir sig og hafa sjúklinginn með í ráđum.

Horfur sjúklinga með óskurðtæk lifrarfrumukrabbamein eru um 8 mánuðir án meðferðar. ${ }^{16}$ Í lok rannsóknartímabilsins var meðallifun sjúklinganna 15,2 mánuðir, en pá voru tveir af 9 sjúklingum látnir. Pví er augljóst að meðallifun á eftir að batna með tímanum. Meðaltími án versnunar sjúkdóms var 11,4 mánuðir og af peim 7 sjúklingum sem eru enn á lífi hafa 5 engin merki um versnun sjúkdómsins. Petta bendir til pess að inngripin séu að bæta lifun pessara sjúklinga.

Einn sjúklingur með lifrarfrumukrabbamein var á lifrarígræðslulistanum fyrir inngrip. Pá niðurstiguðust prír af 8 sjúklingum sem ekki voru á lifrarígræðslulista fyrir inngrip (38\%). Mjög mismunandi er hversu hátt hlutfall sjúklinga tekst að niðurstiga pegar rýnt er í erlendar niðurstöður og var tíðni niðurstigunar allt að 70,5\%. ${ }^{17}$ En hafa ber í huga að sjúklingar voru sérvaldir inn í pá rannsókn og pví ólíku saman að jafna. Pó má segja að árangurinn á Íslandi sé góður, par sem enginn sjúklinganna sem niðurstiguðust hefðu verið valdir inn í pá rannsókn. Einn sjúklingur sem hafði niðurstigast greindist með vaxandi sjúkdóm og féll af listanum par sem fjöldi æxla í lifrinni jókst. Alls hafa pví prír sjúklingar með lifrarfrumukrabbamein farið í lifrarígræðslu eftir að hafa gengist undir inngrip. Hjá einum peirra greindist endurkoma á æxli í lifrinni 19 mánuðum eftir lifrarígræðsluna. Tíðni endurkomu lifrarfrumukrabbameins eftir lifrarígræðslu er breytileg eftir rannsóknum en jafnvel pegar notast er við ströngustu skilyrði í vali á sjúklingum í ígræðslu er tíðni endurkomu $10 \%$ eftir 5 ár. $^{18}$

Alger svörun varð tvisvar og hlutasvörun fjórum sinnum í kjölfar inngripanna hjá sjúklingum með lifrarfrumukrabbamein. Sjúkdómurinn hélst stöðugur í 9 tilvikum en tvisvar versnaði sjúkdómurinn eftir inngripin. Alger svörun eða hlutasvörun varð pví í 35\% tilvika og er pað í samræmi við árangur sem birst hefur í erlendum rannsóknum. ${ }^{19}$

Lifrarstarfsemin hélst óbreytt í flestum tilvikum. Í einu tilviki versnaði lifrarstarfsemin pannig að sjúklingurinn fór úr Child'sflokki A í flokk B í kjölfar IKSS og rafbrennslu. Sjúklingurinn var kominn á lifrarígræðslulistann og pess vegna ákveðið að gera meðferðina ágengari en ella svo að hann myndi ekki falla af listanum. Rúmum einum og hálfum mánuði eftir IKSS og rafbrennsluna fór sjúklingurinn í lifrarígræðslu. Í sumum tilvikum tekur meira en fjórar vikur fyrir lifrina að jafna sig eftir inngrip og pví óvíst hvort um varanlega versnun á lifrarstarfsemi var að ræða. Ekki er talið að sjúklingar sem gengist hafa undir inngripin hafi orðið fyrir varanlegri skerðingu á lifrarstarfsemi eða farið í lifrarbilun sem rekja má til inngripanna.

Í flestum tilvikum dró úr krabbalíkisheilkennum hjá sjúklingum með meinvörp í lifur frá krabbalíki í kjölfar inngripanna. Hins vegar er ekki vitað hversu mikið dró úr einkennunum eða hversu lengi áhrif inngripanna vöruðu. Í erlendum rannsóknum dregur úr krabbalíkisheilkennum í allt að 60\% til 95\% tilvika í kjölfar IKSS og slagæðastíflana. Pá sést bætt lifun hjá sjúklingum sem gangast undir IKSS. ${ }^{20}$ Lifun sjúklinga með meinvörp frá krabbalíki var 61, 156 og 180 mánuðir frá greiningu. Krabbalíki vaxa mun hægar en lifrarfrumukrabbamein og horfur sjúklingsins almennt mun betri. Sjúklingarnir voru búnir að lifa með sjúkdóminn í nokkur ár áður en peir gengust undir inngripin og pví óljóst hvaða áhrif inngripin hafa átt í lifun peirra.

Við 26 inngrip komu upp minniháttar fylgikvillar í 6 tilvikum (27\%). Í einu tilviki var pað vegna tímabundinnar versnunar á krabbalíkisheilkenni en vegna æðastíflunarheilkennis í 5 tilvikum. Erfitt er að bera saman tíðni fylgikvilla á Íslandi og erlendis par sem ekki eru til margar rannsóknir yfir tíðni fylgikvilla. Í ítalskri rannsókn var tíðni fylgikvilla 9,1\%. ${ }^{21}$ Í rannsókninni var æðastíflunarheilkenni ekki skilgreint sem fylgikvilli en tekið fram að $75 \%$ sjúklinga hefðu fengið æðastíflunarheilkenni eftir inngrip. Skráning einkenna var oftast ekki nákvæm í sjúkraskrám Landspítala í kjölfar inngripanna. Æðastíflunarheilkenni gengur yfirleitt yfir á einum til tveim dögum. Af pessum sökum var ákveð¡ð аð miða fylgikvilla við lengda innlögn og endurinnlögn og ástæður í hverju tilfelli skoðaðar. Með pessari aðferð næst raunsæ 
sýn á tíðni klínískt mikilvægra fylgikvilla í kjölfar inngripanna. Í einu tilviki kom upp meiriháttar fylgikvilli pegar sjúklingur með meinvörp frá krabbalíki lést 15 dögum eftir slagæðastíflun. Dánarorsök var talin vera hjartabilun og ekki rakin til inngripsins en sjúklingurinn hafði sögu um hjartasjúkdóm.

Helstu vankantar pessarar rannsóknar eru fáir sjúklingar með stuttan eftirfylgnitíma. Hins vegar væri forvitnilegt að sjá hvernig pessum sjúklingum reiðir af með tímanum og hver árangur IKSS verður pegar fleiri hafa gengist undir inngripin. Pess vegna væri forvitnilegt að endurtaka rannsóknina að nokkrum tíma liðnum. Helstu kostir rannsóknarinnar er að vitað er um afdrif allra sjúklinganna og eftirfylgni $100 \%$. Að auki eru til myndgreiningarannsóknir eftir flest inngripin.

\section{Lokaord}

Árangur staðbundinnar krabbameinsmeðferðar á Íslandi var viðunandi og var tíðni minniháttar og meiriháttar fylgikvilla innan ásættanlegra marka. Meðallifun sjúklinga með lifrarfrumukrabbamein var 15,2 mánuðir og prír af 8 niðurstiguðust og komust á lifrarígræðslulistann. Inngripin virtust ekki hafa valdið varanlegri skerðingu á lifrarstarfsemi eða valdið sjúklingnum skaða að öðru leyti. Hugsanlega væri hægt að rekja góðan árangur staðbundinnar krabbameinsmeðferðar á Íslandi til betri lifrarstarfsemi hjá íslenskum sjúklingum með lifrarfrumukrabbamein miðað við pað sem sést í erlendum rannsóknum. Pessi rannsókn bendir til pess að öruggt sé að gera IKSS á Landspítala, sem sparar fjármuni og minnkar óhagræði fyrir sjúklinga sem ella pyrftu að fara í pessa sérhæfðu meðferð erlendis.

\section{Heimildir}

1. Brown DB, Gould JE, Gervais DA, Goldberg SN, Murthy R, Millward SF, et al. Transcatheter therapy for hepatic malignancy: standardization of terminology and reporting criteria. J Vasc Interv Radiol 2007; 18: 1469-78.

2. Stuart K. Chemoembolization in the management of liver tumors. Oncologist 2003; 8: 425-37.

3. Llovet JM, Real MI, Montana X, Planas R, Coll S, Aponte $\mathrm{J}$, et al. Arterial embolisation or chemoembolisation versus symptomatic treatment in patients with unresectable hepatocellular carcinoma: a randomised controlled trial. Lancet 2002; 359: 1734-9.

4. Liapi E, Geschwind JF, Vossen JA, Buijs M, Georgiades CS, Bluemke DA, et al. Functional MRI evaluation of tumor response in patients with neuroendocrine hepatic metastasis treated with transcatheter arterial chemoembolization. AJR Am J Roentgenol 2008; 190: 67-73.

5. Llovet JM, Burroughs A, Bruix J. Hepatocellular carcinoma. Lancet 2003; 362: 1907-17.

6. Burger I, Hong K, Schulick R, Georgiades C, Thuluvath P, Choti M, et al. Transcatheter arterial chemoembolization in unresectable cholangiocarcinoma: initial experience in a single institution. J Vasc Interv Radiol 2005; 16: 353-61.

7. Sullivan KL. Hepatic artery chemoembolization. Semin Oncol 2002; 29: 145-51.
8. Yamada R, Sato M, Kawabata M, Nakatsuka H, Nakamura $\mathrm{K}$, Takashima S. Hepatic artery embolization in 120 patients with unresectable hepatoma. Radiology 1983; 148: 397-401.

9. A new prognostic system for hepatocellular carcinoma: retrospective study of 435 patients: the Cancer of the Liver Italian Program (CLIP) investigators. Hepatology 1998; 28: 751-5.

10. Kamath PS, Kim WR. The model for end-stage liver disease (MELD). Hepatology 2007; 45: 797-805.

11. Pugh RN, Murray-Lyon IM, Dawson JL, Pietroni MC, Williams R. Transection of the oesophagus for bleeding oesophageal varices. Br J Surg 1973; 60: 646-9.

12. Lencioni $R$, Llovet JM. Modified RECIST (mRECIST) assessment for hepatocellular carcinoma. Semin Liver Dis 2010; 30: 52-60.

13. Bruix J, Sherman M. Management of hepatocellular carcinoma: An update. Hepatology 2011; 53: 1020-2.

14. Palsson PS, Jonasson JG, Olafsson S. Lifrarbólga C: Rannsókn á vefjameinafræði og tengslum við klíníska pætti. Læknablaðið 2008; 94: 13-7.

15. Ludviksdottir D, Skulason H, Jakobsson F, Thorisdottir A, Cariglia N, Magnusson B, et al. Skorpulifur á Íslandi. Faraldsfræðileg rannsókn. Læknablaðið 1996; 82: 836-44.
16. Schafer DF, Sorrell MF. Hepatocellular carcinoma. Lancet 1999; 353: 1253-7.

17. Yao FY, Kerlan RK, Jr., Hirose R, Davern TJ, 3rd, Bass NM, Feng S, et al. Excellent outcome following down-staging of hepatocellular carcinoma prior to liver transplantation: an intention-to-treat analysis. Hepatology 2008; 48: 819-27.

18. Bruix J, Sherman M. Management of hepatocellular carcinoma. Hepatology 2005; 42: 1208-36.

19. Llovet JM, Bruix J. Systematic review of randomized trials for unresectable hepatocellular carcinoma: Chemoembolization improves survival. Hepatology 2003; 37: 429-42.

20. Vogl TJ, Naguib NN, Zangos S, Eichler K, Hedayati A, Nour-Eldin NE. Liver metastases of neuroendocrine carcinomas: interventional treatment via transarterial embolization, chemoembolization and thermal ablation. Eur J Radiol 2009; 72: 517-28.

21. Poggi G, Pozzi E, Riccardi A, Tonini S, Montagna B, Quaretti $\mathrm{P}$, et al. Complications of image-guided transcatheter hepatic chemoembolization of primary and secondary tumours of the liver. Anticancer Res 2010; 30: 5159-64. 


\section{ENGLISH SUMMARY}

\section{Loco-regional therapy for liver malignancy in Iceland}

Bjarnason ThA ${ }^{1}$, Bjarnason $\mathrm{H}^{1,2}$, Bergmann $\mathrm{OM}^{1,3}$, Thorisson $\mathrm{HM}^{1,4,5}$

Background and aims: Transarterial chemoembolization (TACE) is a loco-regional therapy performed to treat tumors in the liver. The branch of the hepatic artery supplying the tumor is catheterized and a mixture of iodized oil, chemotheraputic agents and PVA embolic materials infused. TACE is a palliative treatment of unresectable cancer in the liver but can also be employed as adjunctive therapy to liver resection and/or radiofrequency ablation. The procedure can in certain instances downstage the disease and provide a bridge to liver transplantation. The aim of this study was to evaluate outcome in patients that have undergone loco-regional therapy in Iceland and the frequency and severity of complications related to the procedure.

Material and methods: All Icelandic patients that had undergone TACE, transarterial chemotherapy or bland embolization of liver tumors between 1 May 2007 and 1 March 2011 were included in the study.
Results: Eighteen TACE, six transarterial chemotherapy treatments and two bland embolizations were performed on nine patients withhepatocellular carcinoma (HCC), and three patients with carcinoid metastases in the liver. Mean-survival of patients with HCC was 15.2 months. Survival of patients with carcinoid metastases was between 61 and 180 months. Complete response was achieved twice and partial response four times. The disease remained stable after eleven procedures but progressed after three procedures. Minor complications were diagnosed in 6 of 26 procedures and one major complication. No patient suffered from liver failure due to the procedure. Of the $9 \mathrm{HCC}$ patients, 1 patient was on the liver transplant list before TACE and later underwent successful transplantation. Additionally, 3 of the remaining 8 patients were downstaged and put on to the transplant list.

Key words: Transarterial chemoembolization (TACE), hepatocellular carcinoma (HCC), carcinoid, interventional radiology, loco-regional therapy, bland embolization, transarterial chemotherapy.

Correspondence: Hjalti Már Pórisson hjaltimt@landspitali.is

${ }^{1}$ Faculty of Medicine, Univerity of Iceland, ${ }^{2}$ Department of Radiology, Mayo Clinic, Rochester MN, ${ }^{3}$ Department of Gastro-enterology and ${ }^{4}$ Department of Radiology, Landspitali - University Hospital. ${ }^{5}$ Yale School of Medicine, New Haven CT 